\title{
ANALISIS POTENSI ATAP BANGUNAN KAMPUS SEBAGAI LOKASI PENEMPATAN PANEL SURYA SEBAGAI SUMBER LISTRIK
}

\author{
Elieser Tarigan ${ }^{1}$, Fitri Dwi Kartikasari \\ ${ }^{1}$ Jurusan Teknik Elektro, Universitas Surabaya \\ elieser@staff.ubaya.ac.id \\ ${ }^{2}$ Jurusan Teknik Informatika, Universitas Surabaya \\ fitri_dk@staff.ubaya.ac.id
}

\begin{abstract}
ABSTRAK
Penelitian ini dilakukan dengan simulasi untuk mengetahui potensi pemanfaatan area atap bangunan kampus Universitas Surabaya untuk tempat pemasangan sistem Pembangkit Listrik Tenaga Surya (PLTS). Atap bangunan perpustakaan disimulaskan dan menjadi representasi perhitungan untuk atap bangunan yang lain. Sistem PLTS grid-connected dipakai dalam perhitungan energi listrik PLTS. Hasil penelitian menunjukkan bahwa tersedia area atap bangunan seluas $10.353 \mathrm{~m}^{2}$ yang dapat dimanfaatkan untuk instalasi panel surya. Total kapasitas listrik yang dihasilkan untuk area seluas itu adalah $2.030 \mathrm{kWp}$ atau 2,03 MWp. Kapasitas sebanyak itu terbagi empat, yaitu 630 $\mathrm{kWp}$ dari atap yang menghadap Timur Laut, $535 \mathrm{kWp}$ dari arah Barat Laut, $668 \mathrm{kWp}$ pada arah Barat Daya dan $553 \mathrm{kWp}$ dari arah Tenggara.
\end{abstract}

Kata kunci: PLTS, atap bangunan, panel surya, energi listrik

\section{PENDAHULUAN}

Energi surya merupakan salah satu sumber energi terbarukan yang paling mudah didapat dan berlimpah jumlahnya, yang beberapa waktu belakangan mulai meningkat pemanfaatannya. Energi surya dalam bentuk radiasi dapat dirubah secara langsung menjadi energi listrik dengan menggunakan teknologi photovoltaic (PV) (Benatiallah et al. 2007), yang perangkatnya sering disebut sel surya, serta sistemnya dinamakan pembangkit listrik tenaga surya (PLTS). Pengukuran potensi energi matahari di lokasi yang direncanakan untuk pemasangan sistem PLTS sangat diperlukan dan akan mempengaruhi keberhasilan implementasi sistem itu sendiri. Potensi energi yang akan dihasilkan sangat bergantung pada tingkat sinar matahari di area tersebut (Redweik et al. 2013). Salah satu aspek yang harus diperhatikan untuk mengevaluasi potensi Energi listrik yang dihasilkan dari pemasangan sistem PLTS yang dipasang pada atap bangunan adalah arsitektur bangunan itu sendiri, yaitu identifikasi permukaan atap (datar atau miring), jumlah lantai pada setiap bangunan, dan klasifikasi bentuk atap (Orioli \& Di Gangi 2014).

Teknik simulasi komputer dapat dipakai untuk memprediksi kinerja sistem PV sebelum pemasangan. Teknik ini akan meminimalisasi biaya bahan dan pemasangan (Tarigan et al. 2015). Berbagai penelitian terdahulu telah banyak dilakukan untuk mengukur potensi pemasangan sistem PV pada atap bangunan (Ko et al. 2015). Kuantifikasi potensi PLTS pada atap gedung di Ontario bagian tenggara telah dilakukan oleh Wiginton dkk (Wiginton et al. 2010). Langkah - langkah yang dapat dilakukan untuk menentukan potensi permukaan atap untuk PLTS, antara lain pengambilan sampel, pembagian wilayah secara geografis, menentukan hubungan antara luasan atap dan jumlah penduduk, mengurangkan luasan atap yang tersedia dengan bagian yang tidak terkena sinar matahari atau dipakai untuk keperluan lain, dan konversi ke energi yang dihasilkan. Vardimon (Vardimon 2011) melakukan penelitian tentang area atap yang bermanfaat di Israel. Penelitian tersebut dilakukan dengan menggunakan orthoimages untuk mengekstrak gambar lapisan-lapisan gedung. Luasan atap yang tersedia dihitung dengan data GIS. Dilaporkan bahwa listrik yang dihasilkan oleh sistem PLTS atap ini per tahun setara 
dengan 32\% konsumsi listrik tahunan di Israel. Bergamasco dkk (Bergamasco \& Asinari 2011) mengevaluasi potensi Energi yang dihasilkan oleh sistem PLTS beserta aplikasinya di daerah Pied-mont (Barat Laut Italia). Luas atap yang dapat digunakan untuk aplikasi sistem PLTS dihitung berdasarkan analisis data GIS yang tersedia.

Penelitian ini dilakukan dengan simulasi dengan tujuan mengestimasi luasan dan potensi atap gedung di Universitas Surabaya yang dapat dimanfaatkan untuk pemasangan panel surya. Simulasi juga dilakukan selanjutnya untuk menghitung Energi listrik yang dapat dihasilkan oleh sistem PLTS grid-connected yang terhubung dengan jaringan listrik yang ada. Selain itu, model matematis sederhana dirancang untuk mengestimasi satuan biaya energi listrik dari sistem PLTS yang disimulasikan.

\section{METODOLOGI}

\section{Luas permukaan total}

Pada saat penelitian ini dilaksanakan, terdapat 29 bangunan permanen di kampus Universitas Surabaya. Nama dan lokasi masing-masing bangunan yang diambil dari Google Earth ${ }^{\mathrm{TM}}$ dapat dilihat pada Gambar 1. Aturan penamaan gedung memakai dua huruf kapital. Huruf pertama merupakan inisial nama fakultas dan huruf kedua adalah nama gedung, contohnya EA berarti gedung A fakultas Ekonomi, FB artinya gedung B Fakultas Farmasi. Gedung-gedung tersebut dimanfaatkan untuk berbagai kegiatan akademik, seperti ruang kelas, kantor, perpustakaan, laboratorium, dan kantin. Terdapat beberapa bangunan tidak permanen dan semi permanen yang tidak diikutkan dalam penelitian ini. Bangunan yang diteliti terdiri atas gedung bertingkat yang kondisinya ditunjukkan pada Tabel 1 . Luas permukaan seluruh area kampus dan atap bangunan yang tersedia ditentukan berdasarkan fitur Polygon dari Google Earth ${ }^{\mathrm{TM}}$ (menghitung jarak atau luas dari bentuk-bentuk geometri).

Secara umum arah hadap atap gedung memiliki kemiringan $45^{\circ}$ terhadap mata angin masingmasing menghadap Timur Laut, Tenggara, Barat Daya, dan Barat Laut seperti terlihat pada gambar 1 dan gambar 4. Pada umumnya atap gedung yang menjadi obyek penelitian ini bertipe hip roof dengan subtype Gablet roof atau Dutch roof (Kuchler 2013) yang memiliki 4 sisi dengan arah seperti terlihat pada Gambar 2. Seluruh atap terpasang pada kemiringan $35^{\circ}$ relative terhadap horizontal.

Tabel 1. Kategori Gedung berdasarkan jumlah lantai

\begin{tabular}{cl}
\hline Jumlah lantai & Gedung \\
\hline 2 & EB, FA, TA, PA, International Village, Kantin \\
3 & TB,ED \\
4 & EA, EC, FB, FC, FD, FE,HA,HB,TC, TD, TE, TF,PB, PC, PD, PE \\
6 & FF, FG, Library, TG \\
\hline
\end{tabular}




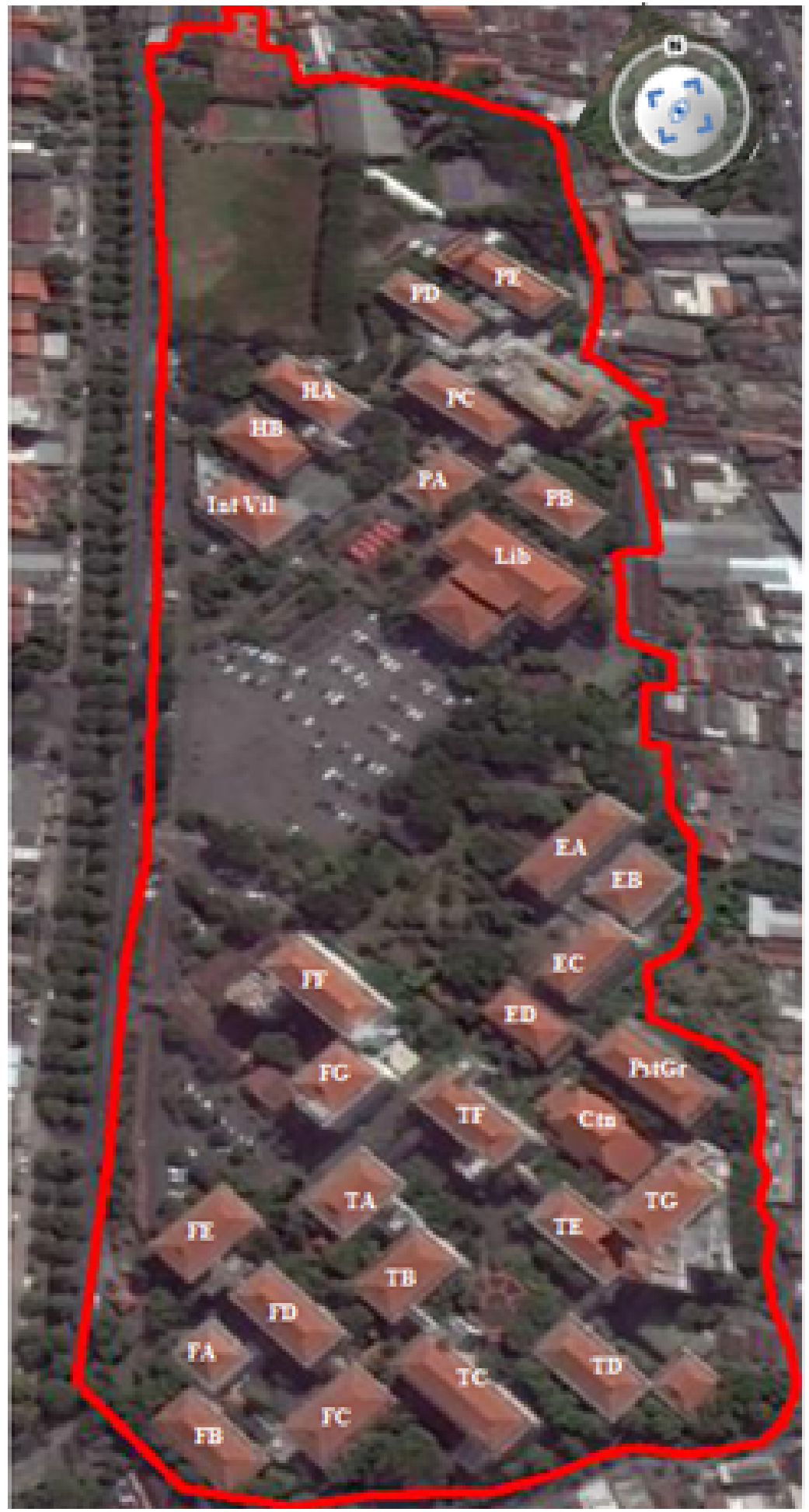

Gambar 1. Peta gedung di Universitas Surabaya diambil dari Google Earth ${ }^{\mathrm{TM}}$ 
Untuk luasan atap, pengukuran dilakukan pada setiap sisi sesuai orientasi geografisnya. Hal ini perlu dilakukan karena simulasi untuk panel surya akan disesuaikan dengan orientasi atap masing-masing gedung.
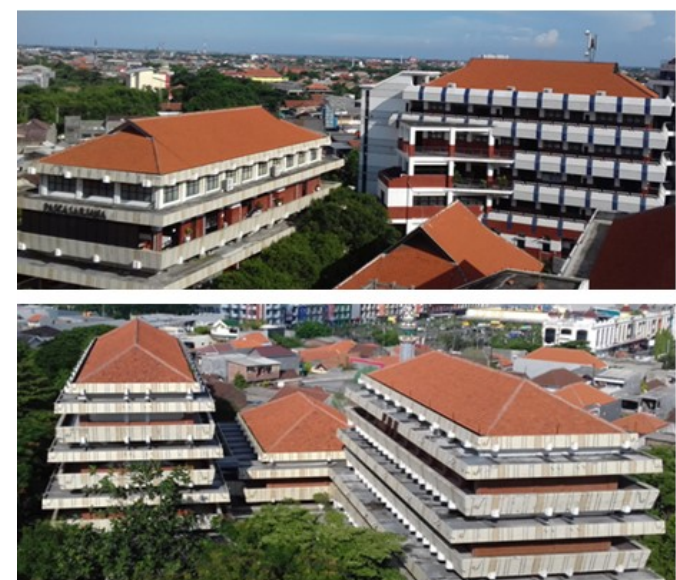

Gambar 2. Tipe atap gablet (atas) dan hip roof (bawah)

\section{Luasan atap yang dapat dimanfaatkan}

Penentuan luasan atap yang dapat dimanfaatkan untuk pemasangan sistem PV didasarkan pada karakteristik geometri masing-masing gedung. Mula-mula dipilih gedung perpustakaan sebagai sampel penelitian. Selanjutnya total luas area atap yang dapat dimanfaatkan dihitung dari peta yang diperoleh melalui aplikasi Google Earth ${ }^{\mathrm{TM}}$ yang diskalakan dengan menggunakan aplikasi Google Sketch. Metode ini juga dapat memberikan estimasi luasan atap yang sudah dipakai untuk hal lain, misalnya poros lift, HVAC, antenna, atau peralatan lain yang dapat mengganggu sistem PV. Selanjutnya dilakukan simulasi dengan berbagai macam spesifikasi panel surya untuk mendapatkan prosentase rata-rata luas permukaan efektif setelah dikurangi dengan elemen pengganggu. Gambar sebenarnya beserta gambar simulasi atap gedung contoh yang akan dipasang sistem panel surya dapat dilihat pada Gambar 3.

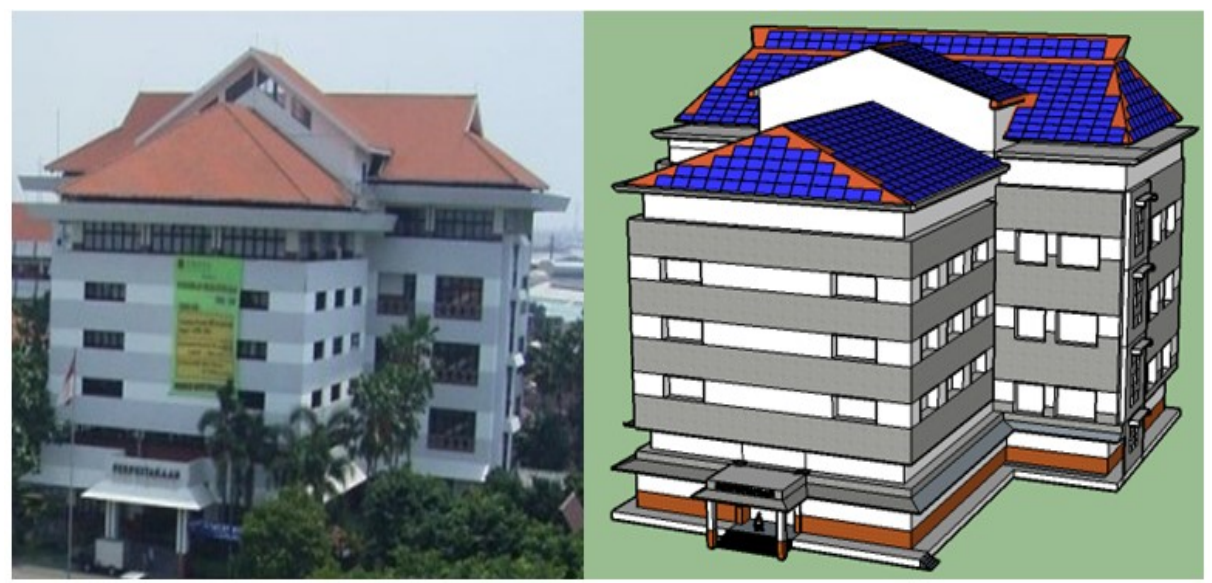

Gambar 3. Gedung perpustakaan untuk simulasi 


\section{Simulasi}

Sistem PLTS grid-connected disimulasikan dengan panel surya yang dipasang selaras dengan orientasi atap gedung. Panel surya yang dipakai dalam simulasi adalah jenis mono crystalline, produksi Sunpower Model SPR-320NE-WHT-D, kapasitas $320 \mathrm{Wp}$ per panel. Peletakan panel surya untuk masing-masing orientasi (arah hadap) atap gedung ditunjukkan pada gambar 4. Setiap sisi permukaan atap dimanfaatkan semaksimal mungkin untuk pemasangan panel surya.

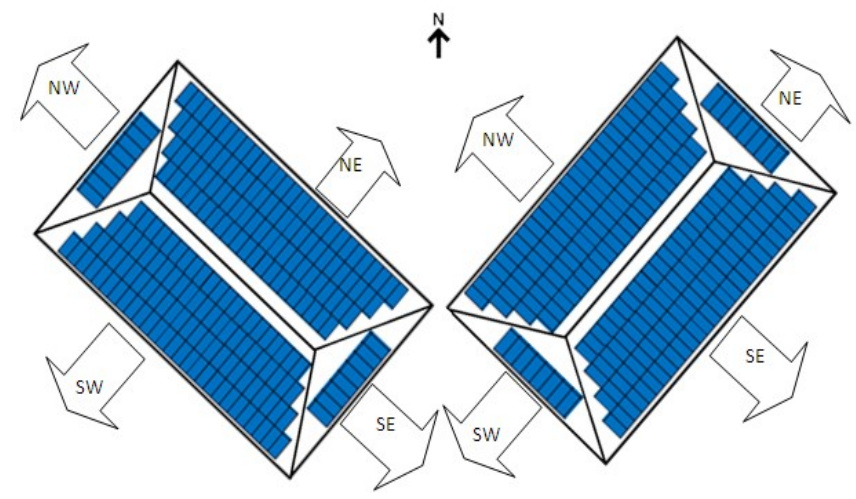

Gambar 4. Peletakkan panel surya untuk gedung yang berbada orientasi

Simulasi sistem PLTS yang terhubung dengan jaringan dilakukan pada salah satu gedung saja, yaitu gedung perpustakaan. Simulasi ini dilakukan untuk mendapatkan estimasi energi yang dihasilkan oleh sistem PV tersebut. Simulasi dilakukan dengan perangkat lunak SolarGIS Pvplanner, sebuah simulator online untuk sistem PLTS. Aplikasi ini menggunakan teknologi pemrograman Google Web Toolkit yang mengintegrasikan model simulasi numerik dari pencatatan data dengan basis data iklim terkini (Marcel S. \& Tomáš C. 2012). Simulator ini menyediakan hasil perhitungan pada wilayah yang dipilih (SolarGis n.d.). Untuk simulasi di gedung perpustakaan, pemasangan panel pada atap di atap dibagi dalam 9 bagian, masingmasing sesuai posisi dan orientasi.

\section{Analisis biaya satuan listrik}

Estimasi harga satuan listrik sistem grid-connected dihitung dengan menggunakan metode yang sudah pernah diaplikasikan pada penelitian sebelumnya (Tarigan et al. 2015). Komponen biaya terdiri atas biaya modul, biaya keseimbangan sistem (balance of sistem) atau BOS, waktu hidup sistem, insentif, dan biaya operasional dan perawatan (O\&M). Biaya total per watt peak dari suatu sistem PLTS dapat dihitung dengan persamaan matematis yang diturunkan. Perhitungan secara numerik dapat dilakukan untuk mengestimasi harga satuan listrik sistem PLTS $\left(C_{p v}\right)$ dengan rumusan berikut:

$$
C_{p v}=\frac{\text { Levelized annual cost }}{\text { Produksi listrik per tahun }}
$$

Levelized annual cost dari suatu sistem PLTS grid-connected terdiri atas biaya operasional dan perawatan, biaya tahunan pengembalian modal, asuransi, pajak, dan lain sebagainya. Biaya tahunan pemulihan modal yang kembali dapat diperhitungkan sebagai komponen biaya modal $C c$ dan factor pemulihan modal dengan hubungan (Kandpal T.C. and Garg H.P. 2003) 


$$
\text { Biaya tahunan pemulihan modal }=C_{c}\left[\frac{r(1+r)^{t}}{(1+r)^{t}-1}\right]
$$

Dengan $\mathrm{C}_{\mathrm{c}}$ adalah biaya modal awal, $r$ adalah tingkat suku bunga, dan $t$ adalah waktu hidup sistem. Jika komponen biaya operasional dan perawatan (O\&M) tahunan diasumsikan $n$ kali biaya modal, sedangkan asuransi, pajak, dan lain sebagainya adalah $m$ kali biaya modal, dengan $0<m, n<1$ maka levelized annual cost dapat dinyatakan sebagai:

$$
\mathrm{C} \text { annual }=C_{c}\left[\frac{r(1+r)^{t}}{(1+r)^{t}-1}+n+m\right]
$$

Berdasarkan factor kapasitas pemanfaatan, (capacity utility factor), $F$ sebuah sistem PLTS, produksi listrik tahunan (annual) dapat diestimasi dengan persamaan berikut

$$
\text { Annual }=(8,760 \times(\text { daya maksimum sistem PLTS }) \times(F)
$$

Persamaan biaya listrik per unit yang dihasilkan oleh sebuah sistem PLTS grid-connected, $C p v$, dapat disederhanakan dengan menyatakan total biaya modal $C c$ sebagai hasil kali dari daya maksimum dan biaya total per watt peak, $C p w$, sebagai berikut

$$
C p v=\frac{C_{p w}\left[\frac{r(1+r)^{t}}{(1+r)^{t}-1}+n+m\right]}{8,760 F}
$$

Perhitungan numerik dilakukan dengan menggunakan persamaan (5) untuk mengestimasi biaya listrik per unit dari suatu sistem PLTS.

\section{HASIL DAN PEMBAHASAN}

Lokasi gedung kampus Universitas Surabaya seperti tertera pada Google Maps ${ }^{\mathrm{TM}}$ adalah di

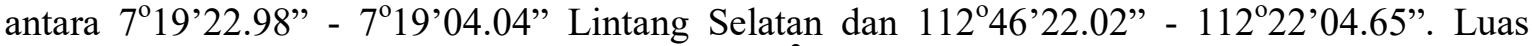
tanah yang ditempati kampus ini adalah $88.020 \mathrm{~m}^{2}$ dengan keliling sepanjang $1535 \mathrm{~m}$. Total luas atap seluruh gedung di kampus Ubaya ini kurang lebih $12.280 \mathrm{~m}^{2}$, atau sekitar $14 \%$ dari luas tanahnya. Atap setiap gedung terdiri atas empat sisi dengan luas total atap yang menghadap timur laut adalah $3.219 \mathrm{~m}^{2}$ atau $26 \%$, menghadap tenggara $2.731 \mathrm{~m}^{2}(22 \%)$, menghadap Barat Daya $3.409 \mathrm{~m}^{2}$ (29\%), dan menghadap Barat Laut $2.821 \mathrm{~m}^{2}$ (23\%). Rinciannya dapat dilihat pada Tabel 2.

Untuk implementasi sistem PLTS pada setiap gedung tetap diperlukan informasi detil serta kajian khusus pada masing-masing gedung. Faktor yang perlu diperhatikan adalah halangan oleh bayangan benda atau bangunan lain di sekitar gedung tersebut ataupun gangguan lain yang bisa disebabkan oleh poros lift, HVAC, antenna dan lainnya. Penelitian sebelumnya yang dilakukan di Spanyol pada tipe atap yang sama menyatakan bahwa luas permukaan atap yang dapat dimanfaatkan adalah 78,9\% (Ordez et al. 2010). Mengacu pada penelitian tersebut, pada 
penelitian ini estimasi luas permukaan atap yang dapat dimanfaatkan dapat dilihat pada kolom kolom kedua dari kanan pada Table 2.

Tabel 2. Luas permukaan atap masing-masing gedung beserta orientasinya

\begin{tabular}{|c|c|c|c|c|c|c|c|c|}
\hline \multirow[t]{2}{*}{ No } & \multirow{2}{*}{$\begin{array}{l}\text { Building's } \\
\text { Name }\end{array}$} & \multirow{2}{*}{$\begin{array}{l}\text { Total } \\
\text { Roof } \\
\text { Area } \\
\left(\mathrm{m}^{2}\right)\end{array}$} & \multicolumn{4}{|c|}{ Roof Area $\left(\mathrm{m}^{2}\right)$ and Orientation } & \multirow{2}{*}{$\begin{array}{c}\text { Estimated } \\
\text { Useful } \\
\text { Area }\left(\mathrm{m}^{2}\right)\end{array}$} & \multirow{2}{*}{$\begin{array}{c}\text { Potential } \\
\text { PV } \\
\text { instalation } \\
(\mathrm{kWp})\end{array}$} \\
\hline & & & $\mathrm{NE}$ & SE & SW & NW & & \\
\hline 1 & EA & 516 & 34 & 224 & 34 & 224 & 439 & 86,1 \\
\hline 2 & EB & 324 & 42 & 120 & 42 & 120 & 275 & 54 \\
\hline 3 & EC & 304 & 26 & 126 & 26 & 126 & 258 & 50,7 \\
\hline 4 & ED & 250 & 90 & 35 & 90 & 35 & 213 & 41,7 \\
\hline 5 & FA & 200 & 50 & 50 & 50 & 50 & 170 & 33,4 \\
\hline 6 & FB & 380 & 140 & 50 & 140 & 50 & 323 & 63,4 \\
\hline 7 & FC & 400 & 40 & 160 & 40 & 160 & 340 & 66,7 \\
\hline 8 & FD & 400 & 160 & 40 & 160 & 40 & 340 & 66,7 \\
\hline 9 & FE & 440 & 50 & 170 & 50 & 170 & 374 & 73,4 \\
\hline 10 & FF & 420 & 170 & 40 & 170 & 40 & 357 & 70 \\
\hline 11 & FG & 320 & 40 & 120 & 40 & 120 & 272 & 53,4 \\
\hline 12 & HA & 420 & 170 & 40 & 170 & 40 & 357 & 70 \\
\hline 13 & HB & 408 & 142 & 62 & 142 & 62 & 347 & 68 \\
\hline 14 & TA & 340 & 30 & 140 & 30 & 140 & 289 & 56,7 \\
\hline 15 & $\mathrm{~TB}$ & 400 & 160 & 40 & 160 & 40 & 340 & 66,7 \\
\hline 16 & $\mathrm{TC}$ & 480 & 40 & 200 & 40 & 200 & 408 & 80 \\
\hline 17 & TD & 360 & 140 & 40 & 140 & 40 & 306 & 60 \\
\hline 18 & $\mathrm{TE}$ & 360 & 140 & 40 & 140 & 40 & 306 & 60 \\
\hline 19 & $\mathrm{TF}$ & 360 & 140 & 40 & 140 & 40 & 306 & 60 \\
\hline 20 & TG & 420 & 40 & 170 & 40 & 170 & 357 & 70 \\
\hline 21 & PA & 280 & 40 & 100 & 40 & 100 & 238 & 46,7 \\
\hline 22 & PB & 330 & 130 & 35 & 130 & 35 & 281 & 55 \\
\hline 23 & PC & 480 & 200 & 40 & 200 & 40 & 408 & 80 \\
\hline 24 & PD & 380 & 160 & 30 & 160 & 30 & 323 & 63,4 \\
\hline 25 & PE & 380 & 160 & 30 & 160 & 30 & 323 & 63,4 \\
\hline 26 & Library & 1400 & 373 & 187 & 563 & 277 & 1.190 & 233,5 \\
\hline 27 & Canteen & 560 & 130 & 150 & 130 & 150 & 476 & 93,4 \\
\hline 28 & $\begin{array}{c}\text { Int. } \\
\text { Village }\end{array}$ & 408 & 142 & 62 & 142 & 62 & 347 & 68 \\
\hline 29 & Post grad. & 460 & 40 & 190 & 40 & 190 & 391 & 76,7 \\
\hline
\end{tabular}

Berdasarkan gambar yang diperoleh dari Google Maps ${ }^{\mathrm{TM}}$ dan dengan bantuan aplikasi Google Sketch Up, dapat dilihat bahwa $85 \%$ dari luasan atap gedung yang dipilih sebagai referensi perhitungan dapat dimanfaatkan untuk penempatan panel surya. Detil penempatan panel surya tersebut seperti ditampilkan pada Gambar 3. Estimasi luasan atap gedung perpustakaan (yang dipakai dalam simulasi) yang dapat dimanfaatkan dapat dilihat pada Tabel 3. Dengan mengasumsikan penggunaan modul surya jenis monokristalin, kapasitas area panel yang dapat digunakan pada atap gedung tersebut dapat disimulasikan. Hasil simulasi menunjukkan bahwa kapasitas total panel yang terpasang di atap gedung perpustakaan tersebut sekitar $233,4 \mathrm{kWp}$. Hasil kajian untuk potensi kapasitas instalasi panel surya untuk masing masing gedung ditujukkan pada kolom paling kanan Tabel 2.

Total kapasitas panel untuk atap seluruh gedung di kampus Universitas Surabaya kemudian dapat diestimasi berdasarkan data dari Tabel 2 serta hasil simulasi pada gedung perpustakaan 
(Tabel 3). Hasil perhitungan menunjukkan bahwa dari $12.180 \mathrm{~m}^{2}$ luas total atap seluruh gedung di kampus Universitas Surabaya, sekitar $10.353 \mathrm{~m}^{2}$ dapat dimanfaatkan untuk pemasangan panel surya.

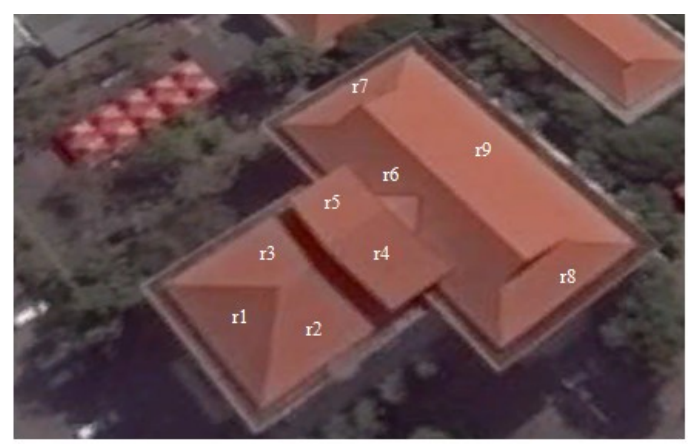

Gambar 6. Bagian atap untuk simulasi

Tabel 3. Potensi Energi atap gedung perpustakaan

\begin{tabular}{ccccc}
\hline Segment & Orientation & $\begin{array}{c}\text { Total Roof } \\
\text { Area }\left(\mathrm{m}^{2}\right)\end{array}$ & $\begin{array}{c}\text { Estimated Useful } \\
\text { Area }\left(\mathrm{m}^{2}\right)\end{array}$ & $\begin{array}{c}\text { Estimated PV panels } \\
\text { Capacity (Wp) }\end{array}$ \\
\hline r1 & SW & 100 & 85 & 16.660 \\
r2 & SE & 104 & 88 & 17.248 \\
r3 & NW & 104 & 88 & 17.248 \\
I4 & SW & 90 & 77 & 15.092 \\
r5 & NW & 90 & 77 & 15.092 \\
r6 & SW & 373 & 317 & 62.132 \\
r7 & NW & 83 & 71 & 13.916 \\
r8 & SE & 83 & 71 & 13.916 \\
r9 & NE & 373 & 317 & 62.132 \\
\hline & & & & Total: 233.436 \\
\hline
\end{tabular}

Total kapasitas keseluruhan panel tersebut adalah $2.030 \mathrm{kWp}$ atau 2,03 MWp yang diperoleh dari keempat sisi atap, masing-masing $630 \mathrm{kWp}, 535 \mathrm{kWp}, 668 \mathrm{kWp}$, dan $553 \mathrm{kWp}$ dari atap yang menghadap Timur Laut, Tenggara, Barat Daya, dan Barat Laut. Simulasi dilakukan menggunakan SolarGIS-pvPlanner untuk mengestimasi Energi yang dihasilkan oleh sistem PV yang dipasang di Surabaya dengan berbagai parameter geometris posisi matahari. Dari hasil simulasi diperoleh data rata-rata produksi Energi per hari untuk panel silicon mono cristaline yang dipasang pada kemiringan $35^{\circ}$ untuk setiap sisi seperti terlihat pada Tabel 4. Sudut kemiringan dipilih berdasarkan kemiringan atap gedung. Perubahan jenis panel surya pada parameter simulasi menunjukkan hasil yang sedikit berbeda. Pada semua kasus, panel yang menghadap Timur Laut menghasilkan Energi tertinggi dibandingkan ketiga orientasi lainnya. Hal ini sesuai dengan posisi Surabaya yang terletak di Selatan garis khatulistiwa.

Produksi energi per bulan dari suatu sistem PLTS grid-connected dapat diestimasi berdasarkan data harian serta kapasitas area yang tersedia pada atap. Hasil simulasi menunjukkan bahwa, jika seluruh atap gedung di Universitas Surabay dimanfaatkan untuk pemasangan panel surya maka produksi energi per bulannya akan berkisar antara $248 \mathrm{mWh}$ sampai $362 \mathrm{mWh}$. Gambar 6 menunjukan total energi per bulan yang dihasilkan dari seluruh atap, masing-masing untuk atap yang menghadap Tenggara, Barat Daya, Timur Laut, dan Barat Laut. 
Tabel 4. Produksi Energi per hari dalam kWh/kWp dari Silicon PV di Surabaya

\begin{tabular}{lccccccccccccc}
\hline & Jan & Feb & Mar & Apr & May & Jun & Jul & Aug & Sept & Oct & Nov & Dec & Avg \\
\hline NW & 3.75 & 3.73 & 3.83 & 3.82 & 3.94 & 4.12 & 4.45 & 4.86 & 5.09 & 4.95 & 4.20 & 3.55 & 4.19 \\
NE & 3.73 & 3.74 & 3.89 & 3.93 & 4.11 & 4.32 & 4.65 & 5.00 & 5.15 & 4.92 & 4.16 & 3.52 & 4.26 \\
SE & 3.79 & 3.74 & 3.79 & 3.72 & 3.79 & 3.92 & 4.23 & 4.67 & 4.95 & 4.89 & 4.22 & 3.59 & 4.11 \\
SW & 3.79 & 3.74 & 3.79 & 3.72 & 4.79 & 4.92 & 4.23 & 4.67 & 4.95 & 4.89 & 4.22 & 3.59 & 4.11 \\
\hline
\end{tabular}

Produksi energi per bulan dari suatu sistem PLTS grid-connected dapat diestimasi berdasarkan data harian serta kapasitas area yang tersedia pada atap. Hasil simulasi menunjukkan bahwa, jika seluruh atap gedung di Universitas Surabay dimanfaatkan untuk pemasangan panel surya maka produksi energi per bulannya akan berkisar antara $248 \mathrm{mWh}$ sampai $362 \mathrm{mWh}$. Gambar 6 menunjukan total energi per bulan yang dihasilkan dari seluruh atap, masing-masing untuk atap yang menghadap Tenggara, Barat Daya, Timur Laut, dan Barat Laut.

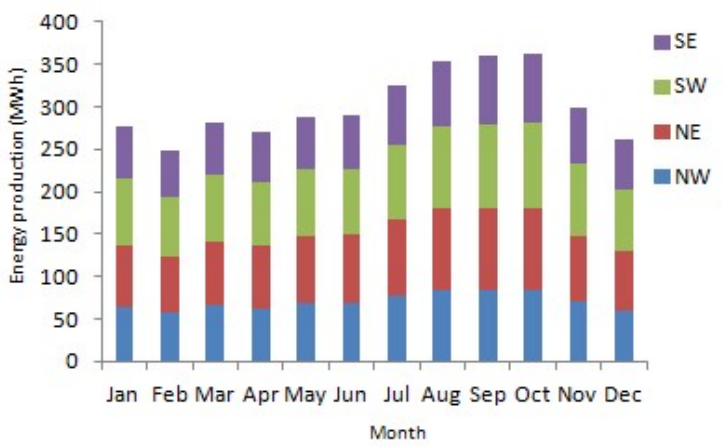

Gambar 6. Produksi Energi per bulan dari sistem PV di atap gedung

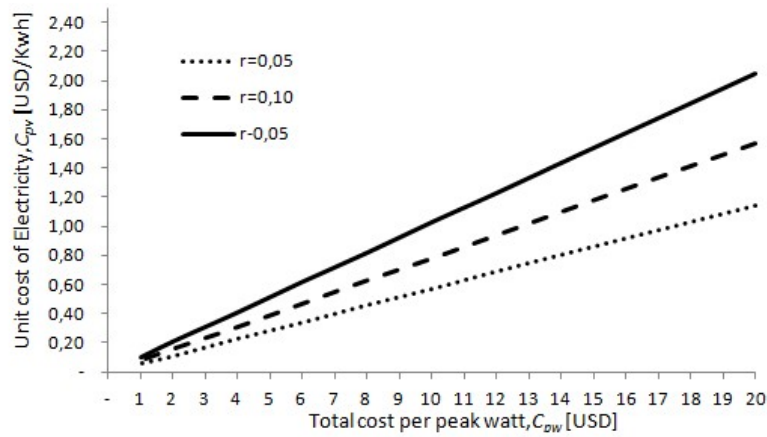

Gambar 7. Biaya per satuan Energi listrik

Estimasi biaya riil per satuan Energi listrik dari sistem PLTS ini dihitung dengan menggunakan persamaan (5). Nilai parameter yang dipakai dalam perhitungan adalah $t=20$ tahun, $n=5 \%, F=$ $20 \%$, dan $\mathrm{m}=0$. Simulasi dilakukan untuk tiga nilai $r$ yang berbeda, yaitu 0,$05 ; 0,10 ;$ dan 0,15 . 
Hasil perhitungan dapat dilihat pada Gambar 7. Berdasarkan nilai konversi dari grafik di atas, pada saat ini rata-rata biaya per satuan Energi listrik $C p w$ berkisar antara 0,30-0,60 USD/kWh.

\section{KESIMPULAN}

Simulasi sistem pembangkit listrik tenaga surya di atap gedung Universitas Surabaya telah dilakukan. Luas total atap seluruh gedung di kampus Universitas Surabaya adalah $12.280 \mathrm{~m}^{2}$. Setiap gedung memiliki atap yang terdiri atas empat sisi, masing-masing menghadap Timur Laut, Tenggara, Barat Daya, dan Barat Laut dengan luasan total masing-masing adalah $3.219 \mathrm{~m}^{2}$ $(26 \%), 2.731 \mathrm{~m}^{2}(22 \%), 3.409 \mathrm{~m}^{2}(29 \%)$, dan $2.821 \mathrm{~m}^{2}$ (23\%). Total kapasitas panel yang dapat dipasang sekitar $2.030 \mathrm{kWp}$ atau 2,03 MWp dengan produksi Energi per bulan berkisar antara $248 \mathrm{mWh}$ sampai $362 \mathrm{mWh}$. Perhitungan biaya per satuan Energi listrik menunjukkan bahwa sistem PV semacam ini memiliki potensi untuk menyediakan listrik dengan harga yang dapat bersaing dengan sumber Energi listrik lainnya, terutama dengan teknologi yang terus berkembang

\section{REFERENSI}

Benatiallah, A. et al., 2007. A simulation model for sizing PV installations. Desalination, 209(1), pp.97-101.

Bergamasco, L. \& Asinari, P., 2011. Scalable methodology for the photovoltaic solar energy potential assessment based on available roof surface area: Application to Piedmont Region (Italy). Solar Energy, 85(5), pp.1041-1055.

Kandpal T.C. and Garg H.P., 2003. Financial evaluation of renewable energy technologies,

Ko, L. et al., 2015. Evaluation of the development potential of rooftop solar photovoltaic in Taiwan. Renewable Energy, 76, pp.582-595.

Kuchler, S., 2013. Solar Energy Assesment Based on Weather Station Data for Direct Site Monitoring in Indonesia. Dalarna University.

Marcel S. \& Tomáš C., 2012. New Web-Based Service Offering Solar Radiation Data and PV Simulation Tools for Europe, North Africa and Middle East. In Eurosun.

Ord????ez, J. et al., 2010. Analysis of the photovoltaic solar energy capacity of residential rooftops in Andalusia (Spain). Renewable and Sustainable Energy Reviews, 14(7), pp.2122-2130.

Orioli, A. \& Di Gangi, A., 2014. Review of the energy and economic parameters involved in the effectiveness of grid-connected PV systems installed in multi-storey buildings. Applied Energy, 113, pp.955-969. Available at: http://dx.doi.org/10.1016/j.apenergy.2013.08.014.

Redweik, P., Catita, C. \& Brito, M., 2013. Solar energy potential on roofs and facades in an urban landscape. Solar Energy, 97, pp.332-341. SolarGis, SolarGis PVPlanner. Available at: http://solargis.info/pvplanner [Accessed June 20, 2006].

Tarigan, E., Djuwari \& Kartikasari, F.D., 2015. Techno-economic Simulation of a Gridconnected PV System Design as Specifically Applied to Residential in Surabaya, Indonesia. Energy Procedia, 65, pp.90-99.

Vardimon, R., 2011. Assessment of the potential for distributed photovoltaic electricity production in Israel. Renewable Energy, 36(2), pp.591-594.

Wiginton, L.K., Nguyen, H.T. \& Pearce, J.M., 2010. Quantifying rooftop solar photovoltaic potential for regional renewable energy policy. Computers, Environment and Urban Systems, 34(4), pp.345-357. 